\title{
De democratische vertegenwoordiging van cliënten en patiënten bij de decentralisaties ${ }^{*}$
}

\author{
Hester van de Bovenkamp \& Hans Vollaard**
}

\section{Inleiding}

Participatie van burgers bij het vormgeven van beleid staat al jaren op de agenda van beleidsmakers in binnen- en buitenland. Deels geïnspireerd door theorieën over participatieve en deliberatieve democratie hebben burgers allerlei mogelijkheden gekregen om hun stem te laten horen in het publieke debat. Onderzoek naar dit soort vormen van directe participatie laat echter zien dat het aantal burgers dat warmloopt voor en gebruikmaakt van deze mogelijkheden beperkt is (Hibbing \& Theiss-Morse, 2002; Dowding \& John, 2009; Michels, 2011; Van Oenen, 2011). De groep die participeert, bestaat veelal uit de hoogopgeleide blanke midden- en bovenklasse die ook op andere plekken al gebruikmaakt van haar democratische inspraakrecht (Veldheer e.a., 2012). Hierdoor blijft de activering van burgers niet alleen beperkt van omvang, maar bestaat ook het gevaar dat vragen en behoeften van niet-actieve burgers minder in beeld komen. Dit ongelijkheidseffect kan nog worden versterkt doordat de actieve burgers een gewilliger oor bij de overheid en andere instellingen vinden als daar mensen van gelijke achtergrond werken. Met termen als diplomademocratie, participatie-elite en diplomabureaucratie is voor deze ongelijkheid in de afgelopen jaren meer aandacht gekomen (Bovens \& Wille, 2011).

Ongelijke participatie staat op gespannen voet met het democratische ideaal van gelijkheid, omdat bepaalde vragen en behoeften minder in beeld kunnen komen (Held, 2006; Verba \& Nie, 1972; Bovens \& Wille, 2011). Het feit dat er ongelijkheid in participatie bestaat tussen groepen, hoeft echter niet per definitie problematisch te zijn. Indien de belangen van niet-participerende burgers worden vertegenwoordigd door anderen, klinkt via de weg van vertegenwoordiging hun stem toch door (Van de Bovenkamp e.a., 2013). Deze vertegenwoordiging kan via gekozen vertegenwoordigers plaatsvinden, maar daarnaast zijn er allerlei niet-gekozen actoren in het publieke debat te vinden die claimen bepaalde groepen burgers te vertegenwoordigen. Het belang van deze niet-gekozen vertegenwoordiging wordt in toenemende mate benadrukt in de theoretische literatuur over vertegenwoordiging en kan een mogelijkheid bieden om ongelijkheid tegen te gaan (Urbinati \&

* De auteurs bedanken Paul Robben, Klaartje Peters, de leden van de Health Care Governance groep van het iBMG en de deelnemers aan de workshop 'Uitdagingen voor het lokale bestuur in tijden van crisis' op het Politicologenetmaal 2014 voor hun commentaar op een eerdere versie van deze paper.

** Dr. Hester van de Bovenkamp is universitair docent bij het Instituut Beleid en Management Gezondheidszorg van de Erasmus Universiteit Rotterdam. vandebovenkamp@bmg.eur.nl Dr. Hans Vollaard is universitair docent Nederlandse en Europese politiek bij het Instituut Politieke Wetenschap van de Universiteit Leiden. vollaard@fsw.leidenuniv.nl 
Warren, 2008; Saward, 2010; Montanaro, 2012). Er is echter nog weinig empirisch onderzoek gedaan naar hoe deze niet-gekozen vertegenwoordiging werkt en hoe deze zich verhoudt tot gekozen vertegenwoordiging.

De huidige decentralisatie van jeugdzorg, arbeidsparticipatie en maatschappelijke ondersteuning in Nederland is bij uitstek een casus waar vertegenwoordiging een belangrijke rol kan spelen om ongelijkheid in participatie tegen te gaan. Deze decentralisaties zijn allereerst bedoeld om op het lokale niveau zo efficiënt mogelijk maatwerk aan cliënten en patiënten te leveren in het sociale domein (Ministerie van Volksgezondheid, Welzijn en Sport, 2013). Een tweede doel is de democratische betrokkenheid van burgers te vergroten (Regeerakkoord VVD-PvdA, 2012). Dit gaat echter niet vanzelf en er wordt dan ook aandacht gevraagd voor de democratische verankering van het nieuwe zorgstelsel (Boogers, 2014; Tweede Kamer 2013/14). Hoewel het lokale niveau op het eerste gezicht geschikt lijkt voor burgerparticipatie, aangezien hier beslissingen worden genomen die burgers direct aangaan, geldt ook hier dat initiatieven met lokale burgerparticipatie vaak een beperkt bereik hebben (Mayer, Edelenbos \& Monnikhof, 2002; Boer \& Van der Lans, 2011). Kwetsbare groepen die op dit moment te maken hebben met de decentralisatie van extramurale begeleiding, jeugdzorg en toeleiding naar werk, zijn bij uitstek groepen die weinig van zich laten horen in democratische fora. In het geval van de decentralisatie van sociaal beleid kunnen deze doelgroepen in theorie echter terugvallen op een veelheid van partijen die hen kunnen vertegenwoordigen. Te denken valt aan gekozen vertegenwoordigers zoals gemeenteraadsleden, maar ook aan niet-gekozen vertegenwoordigers zoals zorgprofessionals, Wmo-raden, en patiëntenorganisaties. In dit artikel bekijken we of en hoe deze vertegenwoordigers kunnen bijdragen aan de democratische kwaliteit van de decentralisaties in het sociale domein. De leidende vragen zijn daarbij: (1) wie claimen patiënten en cliënten te vertegenwoordigen, (2) wat zijn de ervaringen met diverse vormen van vertegenwoordiging, en (3) hoe dragen deze vormen van vertegenwoordiging bij aan de democratische kwaliteit van de lopende decentralisaties?

Deze paper is als volgt opgebouwd. Paragraaf 2 staat stil bij het doel van democratisering dat met decentralisatie naar gemeenten wordt nagestreefd en de problemen die zich voordoen bij directe burgerparticipatie in lokaal Nederland. In paragraaf 3 introduceren we het concept 'vertegenwoordigende claim' (representative claim). Dit concept biedt de mogelijkheid om diverse vormen van vertegenwoordiging, zowel formeel als informeel en zelfbenoemd, in onderlinge samenhang te analyseren. Vervolgens brengen we in paragraaf 4 in kaart welke lokale spelers (kunnen) claimen patiënten en cliënten te vertegenwoordigen in het sociale domein. Daarbij wijst de paper ook meteen op problemen van diverse vertegenwoordigingsclaims. Op grond daarvan biedt de conclusie in paragraaf 5 een voorlopig antwoord op de vraag of en hoe diverse vormen van vertegenwoordiging een bijdrage kunnen leveren aan de democratische kwaliteit van de decentralisaties. 


\section{Decentralisatie en democratisering in het sociale domein}

Decentralisatie en democratisering hangen met elkaar samen. Een van de voordelen van decentralisatie die wel genoemd wordt, is dat ze democratie op lokaal niveau kan versterken (Boogers e.a., 2009). Een belangrijke overweging van de huidige decentralisaties op het gebied van zorg en welzijn is ook om meer maatwerk te kunnen leveren in het sociale domein en zo de publieke kosten te beheersen. Het lokale niveau wordt het meest geschikt geacht om de daadwerkelijke vragen van burgers effectief en efficiënt te beantwoorden. Om meer maatwerk te kunnen leveren zijn participatiemethoden die inzicht bieden in de vragen en behoeften van burgers tegelijkertijd cruciaal.

Het lokale niveau is bij uitstek de plek geweest waar in de afgelopen decennia democratische vernieuwingen hebben plaatsgevonden. Deze vernieuwingen staan in het teken van het stimuleren van burgerparticipatie op lokaal niveau, waarvan verschillende positieve effecten worden verwacht (Michels, 2011). Ten eerste zou participatie 'goede' burgers creëren, aangezien participatie burgers kan helpen om zich verder te ontwikkelen als actieve deelnemers van hun politieke gemeenschap. Dergelijke activering van burgerschap zou het vertrouwen in het eigen politieke kunnen en het vertrouwen in het politieke stelsel versterken. Ten tweede zou participatie van toegevoegde waarde zijn voor de kwaliteit van het beleid. Door middel van burgerparticipatie zouden de vragen en behoeften van burgers directer doorklinken. Met deze doelen voor ogen zijn er talloze instrumenten voor burgerparticipatie ingezet op lokaal niveau, van referenda tot deliberatieve discussiegroepen, die naast het formele vertegenwoordigende kanaal van de gemeenteraad fungeren (Leyenaar, 2009; Michels, 2011). Hoewel steeds meer gemeenten directe burgerparticipatie ook formeel mogelijk maken, lijkt het gebruik ervan af te nemen (De Graaf e.a., 2009). Daarnaast meldt het Sociaal en Cultureel Planbureau (SCP) dat er ondanks de toenemende formele mogelijkheden tot participatie sprake is van een 'afnemend geloof van bewoners in hun invloed op het gemeentebestuur' (Veldheer e.a., 2012, 263). Ook neemt de deelname aan protest- en actiegroepen door burgers af. De algehele conclusie van het SCP is dat '(v)oor maar een heel klein deel van de bevolking blijkt te gelden dat zij de "participatieladder" tot bovenaan willen beklimmen of feitelijk beklimmen.'(Veldheer e.a., 2012, p. 272). Directe burgerparticipatie, zoals al eerder vermeld, blijft vooral een aangelegenheid van mondige, hoger opgeleide, wat oudere blanke mannen, wat ongelijkheid in de hand kan werken (Trappenburg, 2008; Van de Bovenkamp, 2010; Veldheer e.a., 2012). De vragen en behoeften van deze burgers zijn immers niet per definitie gelijk aan die van niet-actieve burgers, zeker niet op het vlak van zorg en welzijn. Een verschil in sociaaleconomische status vertaalt zich bijvoorbeeld in een verschil in hoeveelheid en type gezondheidsproblemen en als gevolg daarvan in verschillend type zorggebruik (Van Oers, 2002; Morone \& Jacobs, 2005; www.tns-nipo.com). Bovendien verschillen vervolgens de ideeën over wat goede zorg is (Van de Bovenkamp, 2010). Het is daarom van belang om naar de ervaringen met democratische vertegenwoordiging te kijken om een oordeel te kunnen vellen over de democratische kwaliteit van de decentralisaties. 


\section{Vertegenwoordigende claims: gekozen én niet-gekozen vertegenwoordiging}

In de literatuur over democratische besluitvorming wordt vertegenwoordiging vaak gezien als surrogaat voor directe participatie van burgers of zelfs als antidemocratisch (Pitkin, 2004; Urbinati, 2006; Mansbridge, 2011). Deze kritische kijk op vertegenwoordiging is in het verleden al betwist door politieke denkers als Edmund Burke. Zij beschouwden verkiezingen juist als een effectief selectiemiddel om politici met verstand van zaken te laten beslissen wat het algemeen belang zou dienen. Het feit dat vandaag de dag maar een klein aantal burgers gebruikmaakt van de talloze mogelijkheden tot directe participatie roept eens te meer de vraag op of het ondergeschikte imago van vertegenwoordiging wel terecht is. Verschillende auteurs pleiten dan ook voor meer aandacht voor vertegenwoordiging en dat vertegenwoordiging als intrinsiek onderdeel van het democratisch bestel gezien moet worden (Plotke, 1997; Urbinati, 2006).

Er is een veelheid van vormen en modellen van democratische vertegenwoordiging beschreven in de literatuur (Manin, Przeworski \& Stokes, 1999; Mansbridge, 2003; Saward, 2009). Deze benaderingen hebben gemeenschappelijk dat ze de relatie tussen vertegenwoordigers en de groep die wordt vertegenwoordigd centraal stellen. De volgende vragen kunnen worden gesteld om invulling te geven aan deze relatie. Ten eerste is er de vraag wie of wat er vertegenwoordigd moet worden (sociale kenmerken, politieke voorkeuren of het algemeen belang). Ten tweede is er de vraag wie deze vertegenwoordigende taak op zich moet nemen (mensen die bepaalde eigenschappen of politieke voorkeuren delen, experts of een combinatie van beide). Ten derde is er de vraag of vertegenwoordigers vooral de focus moeten richten op het dienen van het algemeen belang of van hun specifieke achterban. En nauw daarmee verbonden is de vraag hoe vertegenwoordigers moeten opereren: zijn zij afgezanten of zaakwaarnemers van hun achterban (en vindt vertegenwoordiging daarmee plaats door middel van een strikt mandaat) of zijn vertegenwoordigers onafhankelijk (en vertegenwoordigen zij op basis van hun persoonlijke inschatting) (Pitkin, 1967; Bovens \& Wille, 2011).

Michael Saward heeft de laatste jaren het begrip representative claim (vertegenwoordigende claim) onder de aandacht gebracht. Door vertegenwoordiging vanuit deze invalshoek te benaderen komt een veelheid van mogelijke vertegenwoordigingsrelaties in beeld (Saward, 2006, 2009, 2010). Er bestaan vele actoren, zowel individuen als groepen, die meer of minder expliciet claimen bepaalde groepen burgers te vertegenwoordigen. Dit kunnen formeel gekozen volksvertegenwoordigers zijn. De vertegenwoordigingsrelatie is in dat geval gebaseerd op democratische verkiezingen. Dit is ook de focus van veel van de literatuur over vertegenwoordiging (zie bijvoorbeeld Manin, 1997). Een vertegenwoordigingsrelatie kan echter ook andere vormen aannemen. Te denken valt aan belangengroepen die claimen bepaalde groepen of belangen te vertegenwoordigen. Ook over deze groepen is, bijvoorbeeld in de literatuur over het pluralisme en het corporatisme, al het nodige geschreven (zie Held, 2006). Onderzoek naar belangengroepen laat zien dat deze groepen ongelijkheid in participatie en vertegenwoordiging niet per se verminderen. Sommige belangengroepen blijken makkelijker invloed te krijgen 
dan andere. Bovendien is ook binnen belangengroepen maatschappelijke ongelijkheid zichtbaar (Skocpol, 2003; Held, 2006; Strolovitch, 2006; Bovens \& Wille, 2011; Van de Bovenkamp e.a., 2013). Het nadeel van deze studies is dat ze lang niet alle vormen van vertegenwoordigingsrelaties aan bod laten komen. Informele, tijdelijke of ongeorganiseerde vormen van vertegenwoordiging blijven veelal buiten beeld. Het begrip vertegenwoordigende claim biedt de mogelijkheid om een breder palet aan vertegenwoordigingskanalen in beeld te krijgen.

De basis van deze vertegenwoordigende claims kan verschillen. Daarbij is onderscheid te maken tussen: (a) de positie van de maker van de claim (bijvoorbeeld gekozen via verkiezingen); (b) kernaspecten van identiteit (denk aan kerken die vertegenwoordigingsclaims maken op basis van het geloof); (c) specialistische kennis of expertise (bijvoorbeeld artsen die claimen patiënten te vertegenwoordigen op basis van hun professionele expertise); en (d) nieuwe belangen of stemmen die niet gehoord worden (variërend van Bono, die claimt voor de derde wereld te spreken gebaseerd op gemeenschappelijke menselijke waarden, tot werkende alleenstaande moeders die claimen deze groep te vertegenwoordigen op basis van hun gedeelde identiteit, en ervaringsdeskundigen die een beroep doen op gedeelde belevingen) (Saward, 2009, 2010). Het voordeel van het concept vertegenwoordigende claim is ook dat het de mogelijkheid biedt om meer aandacht te besteden aan de acceptatie van verschillende claims. Een beroep op de 'hardwerkende burger' is zo niet automatisch acceptabel puur en alleen vanwege het feit dat een gemeenteraadslid dat in een raadsvergadering doet als gekozen vertegenwoordiger. Deze claim dient geaccepteerd te worden door het toehorende publiek. Op deze manier zijn vertegenwoordigingsrelaties niet slechts beperkt tot formele structuren, maar betreffen die alle claims in de publieke sfeer, waarbij per onderwerp de 'claimers' en de basis voor acceptatie van claims kunnen verschillen. En juist waar bij formele en georganiseerde vertegenwoordiging door gemeenteraden en belangengroepen het kan gebeuren dat gemarginaliseerde en buitengesloten belangen en groepen niet worden vertegenwoordigd, kunnen nietgekozen, informele vertegenwoordigers dat wél doen (Montanaro, 2012).

De huidige literatuur over vertegenwoordiging biedt nog maar beperkt inzicht in hoe de relatie tussen vertegenwoordigde groepen en belangen enerzijds en nietgekozen actoren die claimen deze groepen te vertegenwoordigen anderzijds vorm krijgt in de praktijk. Ons artikel is er daarom mede op gericht om dat beter in kaart te brengen. Daarvoor kunnen we voortbouwen op de aanknopingspunten die de literatuur biedt om deze relatie te duiden. Als we het over vertegenwoordiging hebben, wordt het belang van responsiviteit van de vertegenwoordigers benadrukt (Pitkin, 1967). Over het algemeen worden daarbij twee condities van cruciaal belang geacht: autorisatie en verantwoording. Autorisatie vereist dat er procedures zijn die de vertegenwoordigden de mogelijkheid geeft om hun vertegenwoordiger te selecteren of aan te sturen. Verantwoording vereist dat de vertegenwoordiger verantwoording kan afleggen over de door hem genomen acties of gemaakte beslissingen (Urbinati \& Warren, 2008). In geval van gemeentebesturen (en deels ook belangengroepen zoals vakbonden) vinden autorisatie en verantwoording plaats via de formele weg van verkiezingen en publieke bekendmaking van plannen, begrotingen, jaarverslagen en jaarrekeningen. Bij andere vertegen- 
woordigende claims kan de vertegenwoordigingsrelatie echter op allerlei andere manieren tot stand komen. Daar hoeft geen sprake te zijn van formele verkiezingen en bekendmaking. Een claim kan immers juist acceptabel zijn als die wordt gedaan buiten de formele structuren om. Saward spreekt in dit geval over authenticiteit van de claim. Het gaat er in geval van een claim daarom om of een claim geaccepteerd wordt bij het relevante toehorende publiek. Dat kan samenvallen met de specifieke achterban of formele besluitvormingsfora, maar dat hoeft natuurlijk niet (denk maar aan Bono, die opkomt voor de belangen van de armen in de derde wereld in het openbare debat). Om van democratische vertegenwoordiging te kunnen spreken wordt daarom benadrukt dat er gezocht moet worden naar alternatieve vormen van autorisatie (bijvoorbeeld lid worden, meedoen aan protesten, het tekenen van petities, et cetera) en verantwoording (bijvoorbeeld opzeggen lidmaatschap, verantwoording via de media, et cetera) (Montanaro, 2012).

Kortom, het voordeel van het perspectief van de vertegenwoordigende claim is dat het in principe alle vormen van vertegenwoordiging omvat. In het vervolg van dit artikel bekijken we de decentralisaties in het sociale domein vanuit het idee van vertegenwoordigingsclaims om een eerste inventarisatie te maken van of de stemmen van burgers die de gevolgen van deze decentralisaties ondervinden gehoord worden in het debat via de weg van vertegenwoordiging. We kijken daarbij naar welke actoren in het debat vertegenwoordigingsclaims maken, wie ze claimen te vertegenwoordigen, op basis waarvan en tot welk toehorend publiek ze zich richten. Daarnaast inventariseren we de verschillende manieren waarop autorisatie en verantwoording plaatsvinden, om op die manier een eerste inzicht te krijgen in alternatieve autorisatie- en verantwoordingsstructuren. We brengen daarnaast de ervaringen die er tot nu toe zijn met deze vertegenwoordigingskanalen in kaart. Op basis van deze analyse doen we in de conclusie een uitspraak over de democratische kwaliteit van de decentralisaties en aanbevelingen voor vervolgonderzoek.

\section{Democratische vertegenwoordiging en decentralisatie}

Op lokaal niveau is er een veelheid aan actoren die vertegenwoordigende claims maken in het geval van de decentralisaties in het sociale domein. De verschillende vormen waarop zij vertegenwoordigen is onder te verdelen in: (1) gekozen vertegenwoordiging, (2) formele niet-gekozen vertegenwoordiging, en (3) informele zelfbenoemde vertegenwoordiging.

\subsection{Gekozen vertegenwoordiging}

Gekozen vertegenwoordiging vormt het eerste lokale vertegenwoordigingskanaal. In deze categorie worden vertegenwoordigingsclaims gemaakt door gemeenteraadsleden, raadsfracties, politieke partijen en gemeenteraden. Autorisatie en verantwoording vinden in dit geval formeel plaats via regelmatige verkiezingen, waarin zittende vertegenwoordigers kunnen worden afgerekend door in hun plaats andere vertegenwoordigers te kiezen. Daarnaast kunnen gemeenteraads- 
leden tussen verkiezingen door ook op verschillende manieren contact onderhouden met hun achterban via onder meer jaarvergaderingen van hun partijen, sociale media en werkbezoeken. Het toehorend publiek van de claims varieert en betreft zowel collega-raadsleden als het gemeentebestuur en kiezers.

Dit vertegenwoordigingskanaal kampt in de praktijk met een aantal problemen. Allereerst loopt de opkomst bij gemeenteraadsverkiezingen sinds de afschaffing van de opkomstplicht in 1970 terug. Bij de gemeenteraadsverkiezingen van 2014 bedroeg de landelijke gemiddelde opkomst 53,8 procent. Daarbij moet worden opgemerkt dat juist lager opgeleiden bij gemeenteraadsverkiezingen minder gebruik van hun stemrecht maken dan hoger opgeleiden (Bovens \& Wille, 2011; www.tns-nipo.com). Hoger opgeleiden domineren zo de autorisatie en verantwoording in dit vertegenwoordigingskanaal. Daardoor zouden de specifieke wensen van lager opgeleiden minder goed kunnen doorkomen. Minister van Binnenlandse Zaken en Koninkrijkrelaties Ronald Plasterk sprak de verwachting uit dat als gevolg van de decentralisaties de opkomst bij de gemeenteraadsverkiezingen in de toekomst omhoog zal gaan, aangezien mensen zich meer betrokken zullen gaan voelen bij hun gemeenten (De Koster, 2014). Volgens kiezersonderzoek was zorg (jeugdzorg, ouderenzorg en gehandicaptenzorg) in 2014 voor kiezers al het belangrijkste thema. De opkomst zou in 2014 mede nog niet zijn gestegen omdat juist lager opgeleiden, die vaker dan gemiddeld met langdurige zorg te maken hebben, nog nauwelijks wisten welke consequenties de decentralisaties voor hen hebben (www.ipsos-nederland.nl; www.tns-nipo.com). De vraag is echter of Plasterks verwachting een vrome wens blijft of dat de opkomst daadwerkelijk omhoog zal gaan. De ervaring met de Europese verkiezingen stemt wat dit betreft niet hoopvol. Bij de verkiezingen voor het Europees Parlement, eveneens zogeheten tweederangsverkiezingen, is de opkomst in ieder geval niet gestegen ook al zijn de bevoegdheden van het Europees Parlement fors uitgebreid in de loop der jaren.

Gemeenteraden zijn in sociaal opzicht geen representatieve afspiegeling van het kiezersvolk. De raden bestaan in grote mate uit mannelijke, hoger opgeleide en blanke leden (zie onder meer Van der Kaap, 2006). Raadsleden die claimen patiënten en cliënten te vertegenwoordigen, wijken daar dus in sociaal opzicht vaak van af. De vraag is in hoeverre dit problematisch is, want burgers lijken minder belang te hechten aan een juiste sociale afspiegeling dan aan een deskundig gemeenteraadslid dat in nauw contact met de burgers met het oog op de lange termijn het algemene belang probeert te dienen (Denters, 2012). Bovendien lijken de politieke voorkeuren tussen gemeenteraden en burgers minder van elkaar te verschillen (Denters, 2012). Niettemin vinden meer en meer mensen dat gemeenteraadsleden 'zich niet zoveel om de mening van mensen zoals ik' bekommeren. In 2006 was dit percentage al gestegen tot 63 (SGBO, 2006).

Als we vervolgens kijken naar hoe gemeenteraden hun vertegenwoordigende rol inhoudelijk vormgeven, blijkt dat ze de nodige instrumenten hebben om corrigerend te kunnen optreden wanneer voorkeuren, vragen en behoeften niet afdoende doorklinken. Te denken valt aan het herzien van beleidskaders en het opleggen van sancties aan de uitvoerende macht. Gemeenteraden worden echter weinig deskundig geacht op het vlak van de Wet maatschappelijke ondersteuning 
(Wmo) (De Klerk, Gilsing \& Timmermans, 2010). Mede door een gebrek aan informatie zouden veel gemeenteraden nog weinig betrokken zijn bij het opstellen van lokaal beleid ten aanzien van hun nieuwe taken (Rekenkamercommissies B4-gemeenten, 2013). Regionale samenwerkingsverbanden leveren in dit verband nog een extra probleem op. Bij de huidige decentralisaties bestaat de nodige kritiek op de gebrekkige betrokkenheid van gemeenteraden bij de (vorming van) bovengemeentelijke regelingen waarin participatie, jeugdzorg en extramurale begeleiding worden ondergebracht (Loots \& Peters, 2013; Van den Berg, 2013; Raad voor het openbaar bestuur, 2013). Deze regionale samenwerkingsverbanden onttrekken zich daarmee feitelijk vaak aan democratische toetsing door de gemeenteraad. Gemeenteraden vormen dus geen onproblematisch vertegenwoordigingskanaal voor patiënten en cliënten in het sociale domein.

\subsection{Formele niet-gekozen vertegenwoordiging}

Naast gemeenteraden zijn er echter andere actoren die claimen burgers te vertegenwoordigen van wie de relatie, ondanks dat ze niet gekozen zijn, gezien kan worden als formele vertegenwoordigingsrelatie. In dit geval rust deze relatie niet op verkiezingen, maar wel op wetgeving die bepaalde actoren aanwijst om een vertegenwoordigende rol te spelen richting gemeente en zorginstellingsbestuur. In deze categorie vinden we onder meer Wmo-adviesraden, cliëntenraden van zorginstellingen en lokale ombudsmannen. Op het vlak van maatschappelijke ondersteuning kunnen deze formele vertegenwoordigers een belangrijke rol vervullen in het vertolken van de vragen en behoeften van groepen burgers die zelf niet of beperkt actief kunnen of willen participeren (Vonk e.a., 2013).

In artikel $11 \mathrm{Wmo}$ is vastgelegd dat gemeenten hun plannen moeten voorleggen aan vertegenwoordigers van representatieve (zonder verdere specificering) organisaties van de kant van vragers op het gebied van maatschappelijke ondersteuning. Daarnaast is expliciet vastgelegd dat het college bij het vormgeven van zijn plannen zich vergewist van de belangen en behoeften van personen die deze belangen en behoeften niet goed kenbaar kunnen maken (artikel 11 lid 4 en artikel $12 \mathrm{Wmo}$ ). Om invulling te geven aan het vereiste vragers te betrekken, hebben de meeste gemeenten Wmo-adviesraden ingesteld, die aangewezen zijn om een vertegenwoordigende rol te spelen. Die raden zijn de meest gebruikte vorm om cliënten en hun organisaties te betrekken bij het Wmo-beleid (Vonk e.a., 2013). Directe autorisatie en verantwoording naar burgers lijken echter beperkt, want Wmo-adviesraden hebben te kampen met een relatieve onbekendheid onder het grote publiek (Cromwijk e.a., 2010).

Ervaringskennis wordt vaak genoemd als de basis van de vertegenwoordigingsclaim van de Wmo-raden. Het idee is dat deze ervaringskennis een aanvullend perspectief biedt op de kennis van beleidsmakers, zorgprofessionals et cetera, en daarmee van essentieel belang is om tot goede besluiten te komen. Dit maakt patiënten die deze ervaringen delen met andere patiënten de aangewezen personen om patiënten te vertegenwoordigen (Van de Bovenkamp, Trappenburg \& Grit, 2010). Wat betreft de groepen die vertegenwoordigd zijn in Wmo-raden zien we dat vooral goed georganiseerde groepen burgers hun weg vinden naar de raden. Veelal hebben de raden vertegenwoordigers van ouderen en mensen met 
een lichamelijke beperking in hun midden. Dak- en thuislozen, mensen met een verstandelijke handicap, jeugdigen, mensen met chronische psychische problematiek, slachtoffers van huiselijk geweld en mensen van diverse culturele achtergrond zijn er echter minder tot niet present (Van de Bovenkamp e.a., 2010; De Klerk e.a., 2010). De contacten tussen kwetsbare groepen die 'nieuw' zijn op lokaal niveau (zoals jongeren) en de adviesraden blijken daarmee beperkt. De relatie met de achterban komt verder onder druk door de manier waarop er in de Wmo-raden gewerkt wordt, waarbij een grote nadruk ligt op het uitbrengen van adviezen op beleidsplannen van de gemeente. Daarbij doet zich het probleem voor dat niet alle leden van Wmo-adviesraden hun ervaringsdeskundigheid met 'beleidsvaardigheid' kunnen combineren. In toenemende mate blijken raden daardoor uit leden te bestaan die op persoonlijke titel zitting hebben en de capaciteiten hebben om doelgroep overstijgend en beleidsmatig mee te denken (Van Munster e.a., 2012). Dit zijn vaak de mensen zonder specifieke ervaringsdeskundigheid en dat gemis wordt gevoeld. Dergelijke ongebonden leden beperken bovendien veelal nauw en intensief contact met één of meerdere doelgroepen van de Wmo, waardoor autorisatie en verantwoording onder druk komen. Gemeentebesturen zijn soms ook kritisch over de vertegenwoordigingskwaliteiten van Wmo-raden; de 'stem van de burger' en de verwachte ervaringsdeskundigheid van de raden zouden niet altijd voldoende doorklinken, aangezien uit de adviezen niet blijkt wat mogelijke effecten van het beleid zijn voor de verschillende doelgroepen (Van Klaveren \& Poortvliet, 2011). Overigens betrokken gemeentebesturen Wmo-raden vaak te laat bij beleidsvorming, wat hun invloedsmogelijkheden verkleint (Lub, Sprinhuizen \& Cromwijk, 2010; Penning, 2009).

Naast Wmo-adviesraden zijn er nog andere vormen van formele niet-gekozen vertegenwoordiging. Cliëntenraden van zorginstellingen kunnen bijvoorbeeld een vertegenwoordigende rol spelen, aangezien zorginstellingen contracten met gemeenten moeten afsluiten over te leveren zorg. Heel wat cliëntenraden van zorginstellingen zouden op dit moment echter nog beperkt betrokken zijn bij de ontwikkelingen in het lokale beleid (Oudenampsen \& Nederland, 2013). Ook cliëntenraden zijn door wetgeving aangewezen om een vertegenwoordigende rol te spelen. De Wet medezeggenschap cliënten zorginstellingen (WMCZ) geeft deze raden de taak om de 'gemeenschappelijke belangen van de cliënten te behartigen' en bepaalt dat er gezorgd moet worden dat de raad 'redelijkerwijze representatief kan worden geacht voor de cliënten' (artikel 2 lid 1 en artikel 2 lid 3 onderdeel a WMCZ). Net als bij Wmo-raden wordt daarbij benadrukt dat cliënten op basis van hun ervaringskennis deze rol kunnen vervullen. Ook hier doen zich echter problemen voor bij het vinden van dit type vertegenwoordigers, en net als bij Wmoraden is dit deels ingegeven door de manier waarop participatie in dit type forum wordt vormgegeven. Participatie in cliëntenraden vraagt veel van vertegenwoordigers. Zij moeten zich immers buigen over ingewikkelde beleidsstukken, zoals fusies, financiële jaaropgaven en strategische plannen van de instelling (Schillemans, Van de Bovenkamp \& Trappenburg, te verschijnen). Veelal wordt daarom geconstateerd dat de kwaliteit van deze raden onder de maat is en dat raadsleden moeten professionaliseren om hun taak uit te kunnen oefenen (De Savornin Lohman e.a., 2000; Hoogerwerf, Nievers \& Scholten, 2004; Van der 
Kraan \& Meurs, 2008). Het idee dat vertegenwoordiging gebaseerd moet zijn op een gemeenschappelijke identiteit van vertegenwoordigers met de groep die zij vertegenwoordigen, wordt daarom vaak losgelaten in de praktijk. Vaak zijn cliëntenraadsleden voormalige cliënten of zijn zelfs nooit cliënt geweest (Hoogerwerf e.a., 2004; Trappenburg, 2008). Bovendien ligt het gevaar van institutionalisering op de loer, wat de vraag oproept of raadsleden de belangen van cliënten goed vertegenwoordigen (Schillemans e.a., te verschijnen; De Savornin Lohman e.a., 2000; Hoogerwerf e.a., 2004; Van der Kraan \& Meurs, 2008).

We kunnen concluderen dat wetgeving bepaalde actoren, zoals Wmo-raden en cliëntenraden, aanwijst om burgers te vertegenwoordigen. Van autorisatie en verantwoording naar de achterban is echter veelal weinig sprake. Beide formele kanalen van vertegenwoordiging kampen met problemen in de praktijk. Zo blijken alleen bepaalde groepen zitting te nemen in dit type fora, en zijn vooral vertegenwoordigers van de kwetsbare groepen die te maken hebben met de huidige decentralisaties beperkt tot niet present. Bovendien verdwijnt de gewenste ervaringskennis naar de achtergrond door de opzet van het participatieforum, wat de vraag oproept in hoeverre de raden inhoudelijk in staat zijn hun achterban te vertegenwoordigen. Meer contacten met de achterban worden dan ook bepleit, die ook de autorisatie en verantwoording van deze fora zouden kunnen versterken. Het is echter de vraag of raadsleden dit op kunnen pakken, aangezien zij vrijwilligers zijn die maar beperkt de tijd hebben om deze vertegenwoordigingstaak uit te voeren.

\subsection{Informele zelfbenoemde vertegenwoordiging}

De rijksoverheid merkte al op dat er voor kwetsbare groepen ook andere manieren dan bovengenoemde formele kanalen nodig zijn om hen te betrekken bij het Wmo-beleid (Tweede Kamer 2009/10). In het kader van de decentralisatie van de jeugdzorg worstelen gemeenten echter om een diverse groep te laten participeren, ook buiten de Wmo-adviesraden om (Van der Gaag, Glisen \& Mak, 2013). Dat komt deels door gebrek aan tijd en middelen, maar ook door gebrek aan inzicht in wat goed zou werken. Meer oog voor informele zelfbenoemde vertegenwoordigers kan echter belangrijk zijn om de stemmen van kwetsbare groepen te laten doorklinken en horen. Dergelijke vertegenwoordigers zijn niet formeel geautoriseerd om een vertegenwoordigende rol uit te oefenen, maar doen dat wel in de praktijk (Urbinati \& Warren, 2008; Saward, 2006, 2009). Te denken valt aan zorgverleners als artsen en inloophuizen, woningbouwcorporaties, patiënten- en cliëntenorganisaties, vrouwenorganisaties, verzekeraars, kerken, wetenschappers, media en burgerinitiatieven. Zij maken uiteenlopende vertegenwoordigingsclaims, gericht op een uiteenlopend publiek, die bijvoorbeeld gebaseerd zijn op gemeenschappelijke ervaringen (patiëntenorganisaties, lokale burgerinitiatieven), professionele kennis (zorgverleners en wetenschappers) of overstijgende waarden of principes (kerken). Er is echter nog weinig zicht op hoe deze actoren hun vertegenwoordigende rol uitoefenen en hoe hun activiteiten zich tot elkaar verhouden op het vlak van zorg en welzijn op lokaal niveau. Wel kunnen we op basis van analyse van het landelijke debat over de decentralisaties iets zeggen over de mogelijke rol 
die deze actoren op het lokale niveau kunnen gaan spelen door een aantal voorbeelden te bespreken.

In Nederland bestaan honderden landelijke aandoeningspecifieke patiëntenorganisaties (zoals de Borstkankervereniging Nederland en de Nierpatiëntenvereniging Nederland). Deze organisaties hebben zich samen georganiseerd in verschillende koepelorganisaties die ziekte-overstijgende belangenbehartigingsactiviteiten voor hun rekening nemen. Patiëntenorganisaties hebben veelal een formele autorisatie- en verantwoordingsstructuur in de vorm van lidmaatschap van de organisatie en algemene ledenvergaderingen. Deze organisaties claimen echter niet alleen voor hun leden maar voor de bredere patiëntengroep te spreken. De Nationale Patiënten en Consumenten Federatie (NPCF) is daar een voorbeeld van:

'Met die informatie [NPCF-zorgpanel, de vragen en ervaringen die patiënten melden bij de NPCF-Zorglijn en de beoordelingen op ZorgkaartNederland.nl] en met de vakkennis die de NPCF in huis heeft, oefent zij namens iedereen die nu of in de toekomst zorg nodig heeft, invloed uit op het beleid binnen de gezondheidszorg. Daarmee geeft patiëntenfederatie NPCF patiënten een stem, in de spreekkamer, in de politiek, bij de zorgverzekeraar, en in het nieuws.' (www.npcf.nl) $)^{1}$

In de decentralisatiecasus hebben nationale professionele patiëntenorganisaties, waaronder de NPCF, ${ }^{2}$ zich in het debat geroerd. Directeur van de NPCF, Wilna Wind, claimde daarbij 'kwetsbare mensen' te vertegenwoordigen. Het streven om zorg dicht bij huis te leveren werd door haar onderschreven, maar daarbij moest het uitgangspunt zijn 'dat we zorg kunnen blijven garanderen voor kwetsbare mensen, waar ze ook wonen' (Wind, 2013). Hoewel er geen formele autorisatieen verantwoordingsstructuur aanwezig is voor deze brede claim, kan de claim in het publieke debat wel geaccepteerd dan wel verworpen worden door de geclaimde achterban, zij het door ouderen zelf, zij het door andere partijen die deze groep claimen te vertegenwoordigen. Discussies in tv-programma's, kranten en bij hoorzittingen van de Tweede Kamer boden bijvoorbeeld gelegenheid om de vertegenwoordigende claims van de NPCF te toetsen. Autorisatie en verantwoording kregen verder vorm via de likes die mensen op de Facebook-pagina van de NPCF gaven.

Ook het vertegenwoordigingskanaal van patiëntenorganisaties kent echter problemen. De vertegenwoordigingsclaim van patiëntenorganisaties vindt zijn basis veelal in de gedeelde ervaringen die patiënten hebben. Bij patiëntenorganisaties zijn echter in toenemende mate professionele vertegenwoordigers te vinden die ofwel zelf geen patiënt zijn, ofwel 'professionele' patiënten zijn geworden, wat vragen heeft opgeroepen over in hoeverre zij hun brede achterban kunnen vertegenwoordigen. Bovendien bestaan er signalen dat patiëntenorganisaties zijn ingekapseld in formele beleidscircuits (Van de Bovenkamp e.a., 2010). Onderzoek naar lokale takken van patiëntenorganisaties is nog maar zeer beperkt aanwezig. Mogelijk zijn zij nog minder ingekapseld en leunen zij in sterkere mate op hun eigen ervaringen die belangrijk kunnen zijn bij het vormgeven van het gemeente- 
lijke beleid. De bezuinigingen die met de decentralisaties gepaard gaan, kunnen roet in het eten gooien, aangezien de financiële steun voor lokale patiënten- en cliëntenorganisaties om de wensen van hun achterban te ondersteunen slinkt (Oudenampsen \& Nederland, 2013).

Ook zorgprofessionals hebben zich, zowel in organisatorisch verband als op persoonlijke titel, in het landelijke debat over de decentralisaties meerdere keren opgeworpen als vertegenwoordigers van kwetsbare groepen burgers. Artsenorganisaties als de landelijke artsenfederatie Koninklijke Nederlandsche Maatschappij tot bevordering der Geneeskunst (KNMG) en het Nederlands Huisartsen Genootschap (NHG) hebben bijvoorbeeld hun zorgen geuit richting het ministerie, het parlement en in het publieke debat, over met name de decentralisatie in de jeugdzorg (KNMG, 2013, 2014a; NHG/LHV, 2013). De KNMG claimt daarbij uitdrukkelijk burgers te vertegenwoordigen door aandacht te vragen voor het gevaar dat de jeugdzorg minder toegankelijk zou worden en dat er rechtsongelijkheid 'voor deze erg kwetsbare en afhankelijke groep in onze samenleving' zou kunnen ontstaan (KNMG, 2014b, 2). Naast initiatieven in georganiseerd verband bemoeien zorgprofessionals zich op individuele titel met het decentralisatiedebat. Zo roerden zorgprofessionals zich in de media en starten enkele psychiaters een petitie, wat gezien kan worden als alternatief autorisatiekanaal, tegen de transitie in de jeugdzorg waarbij ze zich als vertegenwoordigers voor kinderen opstelden. De oproep 'wij hebben uw hulp nodig om goede zorg voor kinderen veilig te stellen' vond gehoor bij een brede achterban, waaronder ouders, psychologen, raden van bestuur van GGZ-instellingen, leerkrachten et cetera (www.petitiejeugdggz.nl). ${ }^{3}$ In de media werd eveneens verantwoording afgelegd. Een van de initiatiefnemers, kinderpsychiater Menno Oosterhoff, verwoordde daar zijn motivatie om actief te worden met een beroep op zijn professionele identiteit: 'Ik ben arts en dáárom ben ik bezorgd.' Net als artsenorganisaties die invloed probeerden uit te oefenen op de decentralisatie, deed hij in zijn betoog een beroep op het recht van gelijke toegang tot zorg (De Volkskrant, 2013):

'Het is principieel onjuist om gemeenten te laten bepalen of een kind autistisch is of anorexia heeft. Of dat een gemeente kan zeggen dat een kind met adhd maar wat meer moet sporten. Kinderen hebben recht op medische zorg. Maar kinderen met psychiatrische aandoeningen zijn dan niet langer verzekerd en de gemeente bepaalt en betaalt. Kinder- en jeugdpsychiatrie is medische zorg en die is collectief geregeld via de Zorgverzekeringswet. Je moet die niet overhevelen naar gemeenten en kinderen uit de verzekering halen. Waarom heeft een kind met leukemie wel recht op medische zorg en een kind met anorexia niet? Dat is discriminerend. Als je die hulp niet meer wilt verlenen, zeg dat dan.'

Ook zorgverzekeraars mengden zich in het debat over de decentralisaties. Zo pleitten zij, vanuit hun 'grote maatschappelijke verantwoordelijkheid', voor uitstel van de Wet langdurige zorg met een beroep op de kwetsbare burger. Dat deden ze in een openbare brief aan de Tweede Kamer, zodat hun claim ook kon worden getoetst in media en parlement: 'De veranderingen voor de zorg voor 
kwetsbare ouderen, ernstig zieke kinderen of mensen met langdurige psychische problematiek vragen om grote zorgvuldigheid' (Rouvoet, 2014).

Verzekeraars hebben in het Nederlandse zorgstelsel een belangrijke taak toegewezen gekregen om zowel de kwaliteit als de betaalbaarheid van zorg te borgen en te verbeteren. Op de zorgverzekeringsmarkt vormt het switchen van zorgverzekeraar (exit) een alternatief autorisatiekanaal. Er kunnen echter vraagtekens worden geplaatst of verzekeraars worden geaccepteerd als vertegenwoordigers van (kwetsbare) burgers, omdat zij zich met name zouden richten op de kosten. Zo hebben verzekerden over het algemeen minder vertrouwen in hun verzekeraar dan in hun zorgverleners en laten ze zich niet zo makkelijk leiden door sturing van hun verzekeraar (Boonen, 2009). Dit gebrek aan vertrouwen roept de vraag op in hoeverre de vertegenwoordigingsclaim van verzekeraars ook steun zal vinden bij een breed publiek.

Kerken kunnen ook een vertegenwoordigende rol spelen en zijn in dit artikel het laatste voorbeeld dat we willen bespreken. Kerken verstrekken eerst en vooral maatschappelijke ondersteuning in eigen kring en daarbuiten. Daarnaast heeft de lancering van de Wmo kerken uitgedaagd tot een nadere reflectie op hun maatschappelijke rol. Daarbij zien de twee grootste kerkgenootschappen, de Protestantse Kerk Nederland en de Rooms-Katholieke Kerk Nederland, voor zichzelf een rol om nood te signaleren en belangen te behartigen, zowel lokaal als nationaal (Rooms-Katholieke Kerk, 2007; Protestantse Kerk Nederland, z.j.). Dat gaat van het informeren van raadsleden en het opzetten van een juridisch steunpunt voor dak- en thuislozen tot het aanklagen van de Nederlandse staat over de behandeling van mensen zonder verblijfsrecht. Over de rol van de kerken bij de decentralisaties is nog weinig onderzoek gedaan (maar zie Blauw, 2010; Noordegraaf, 2012). Noordegraaf (2012) laat zien dat de rol die kerken spelen bij de Wmo bescheiden is en bovendien per gemeente sterk verschilt. In een aantal gevallen hebben kerken wel contacten met gemeenten en overleggen zij over beleid. Dit kan via de Wmo-raden, waar kerken soms zitting in hebben, maar ook via andere kanalen gebeuren. Het blijkt wel moeilijk deze rol te spelen, onder andere omdat er onder ambtenaren weinig kennis over kerken bestaat, wat de mogelijkheden om gehoord te worden beperkt. Bovendien hebben kerken niet altijd de benodigde kennis over beleidstaal en beleidsdenken. Het belang van een actieve rol wordt door gemeenten en kerken zelf wel bepleit vanuit het idee dat kerken een goed beeld hebben van vragen die er leven (Noordegraaf, 2012). In het publieke debat kunnen de vertegenwoordigingsclaims van kerken worden getoetst. Ze moeten daarbij wel de argwaan overwinnen of ze opkomen voor de belangen van cliënten en patiënten of voor hun eigen religieuze doeleinden.

Kortom, er is een brede variëteit aan informele zelfbenoemde vertegenwoordigers te identificeren. Autorisatie en verantwoording krijgen een andere vorm dan bij formele vertegenwoordigers, bijvoorbeeld via opzeggen of aanmelden voor lidmaatschap, het publieke debat in de media en het parlement, het tekenen van een petitie of een beroep op professionele expertise of overstijgende waarden. Wat opvalt is dat deze actoren juist claimen de kwetsbare groepen burgers te vertegenwoordigen die de consequenties van de decentralisaties zullen ondervinden. Daarmee kunnen ze als een potentieel belangrijke aanvulling worden gezien in de 
vertegenwoordiging van cliënten en patiënten in het sociale domein. Wel zijn ze daarbij sterk afhankelijk van bijvoorbeeld media en parlement of die de ruimte geven hun claim te maken en autorisatie en verantwoording via het publieke debat te laten plaatsvinden. In tabel 1 maken we op basis van het voorafgaande een samenvatting van actoren die vertegenwoordigingsclaims maken, wie of wat zij claimen te vertegenwoordigen en wat de basis van deze claims is, de autorisatie- en verantwoordgingsstructuren en de ervaringen met deze vertegenwoordigingskanalen.

Tabel 1. Verschillende vormen van vertegenwoordiging bij de decentralisaties

\begin{tabular}{|c|c|c|c|c|c|}
\hline & $\begin{array}{l}\text { Actoren die } \\
\text { vertegen- } \\
\text { woordigings- } \\
\text { claims maken }\end{array}$ & - & $\begin{array}{l}\text { Vertegenwoor- } \\
\text { digings- } \\
\text { claim: wie/wat } \\
\text { wordt verte- } \\
\text { genwoordigd en } \\
\text { op basis waar- } \\
\text { van }\end{array}$ & $\begin{array}{l}\text { Autorisatie, verant- } \\
\text { woording en beoogd } \\
\text { toehorend publiek }\end{array}$ & $\begin{array}{l}\text { Ervaringen met ver- } \\
\text { tegenwoordigingska- } \\
\text { naal }\end{array}$ \\
\hline $\begin{array}{l}\text { Gekozen } \\
\text { vertegen- } \\
\text { woordiging }\end{array}$ & $\begin{array}{l}\text { Gemeente- } \\
\text { raden, raads- } \\
\text { leden, raads- } \\
\text { fracties, } \\
\text { politieke par- } \\
\text { tijen }\end{array}$ & - & $\begin{array}{l}\text { Wie: kiezers, } \\
\text { algemeen } \\
\text { belang } \\
\text { Basis: kiezers- } \\
\text { mandaat }\end{array}$ & $\begin{array}{ll}\text { - } & \text { Formele autori- } \\
\text { satie en verant- } \\
\text { woording via } \\
\text { verkiezingen; } \\
\text { - } \quad \text { Informele auto- } \\
\text { risatie en ver- } \\
\text { antwoording via } \\
\text { ledenvergade- } \\
\text { ringen, social } \\
\text { media, werkbe- } \\
\text { zoeken etc. } \\
\text { Toehorend } \\
\text { publiek: raad en } \\
\text { kiezersvolk }\end{array}$ & $\begin{array}{l}\text { Opkomst laag, } \\
\text { met name } \\
\text { onder laagopge- } \\
\text { leide zorgge- } \\
\text { bruikers } \\
\text { Raadsleden zijn } \\
\text { geen represen- } \\
\text { tatieve afspiege- } \\
\text { ling van bevol- } \\
\text { king, kiezers } \\
\text { vinden exper- } \\
\text { tise belangrij- } \\
\text { ker, echter: } \\
\text { Gemeenteraden } \\
\text { kampen met } \\
\text { gebrek aan } \\
\text { expertise }\end{array}$ \\
\hline $\begin{array}{l}\text { Formele } \\
\text { niet-gekozen } \\
\text { vertegen- } \\
\text { woordiging }\end{array}$ & $\begin{array}{l}\text { Wmo-raden, } \\
\text { cliëntenraden }\end{array}$ & $\begin{array}{l}- \\
- \\
-\end{array}$ & $\begin{array}{l}\text { Wie: doelgroe- } \\
\text { pen maatschap- } \\
\text { pelijke onder- } \\
\text { steuning } \\
\text { Basis: ervarings- } \\
\text { deskundigheid }\end{array}$ & 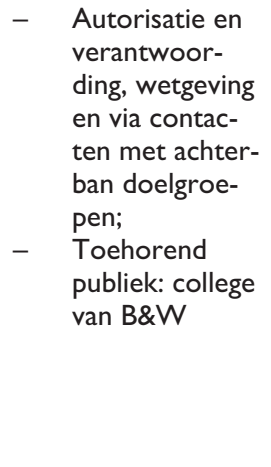 & $\begin{array}{ll}- & \text { Beperkte con- } \\
\text { tacten met ach- } \\
\text { terban } \\
\text { - } \quad \text { Niet alle doel- } \\
\text { groepen pre- } \\
\text { sent } \\
\text { - } \\
\text { Ervaringsdes- } \\
\text { kundigheid ver- } \\
\text { dwijnt ten } \\
\text { koste van } \\
\text { belang doel- } \\
\text { groep overstij- } \\
\text { gend en beleids- } \\
\text { matig denken }\end{array}$ \\
\hline
\end{tabular}




\begin{tabular}{|c|c|c|c|c|c|c|}
\hline $\begin{array}{l}\text { Informele } \\
\text { zelfbe- } \\
\text { noemde ver- } \\
\text { tegenwoordi- } \\
\text { ging }\end{array}$ & $\begin{array}{l}\text { Zorgver- } \\
\text { leners, } \\
\text { patiëntenor- } \\
\text { ganisaties, } \\
\text { verzekeraars, } \\
\text { lokale burger- } \\
\text { initiatieven, } \\
\text { kerken, } \\
\text { wetenschap- } \\
\text { pers, media } \\
\text { etc. }\end{array}$ & - & $\begin{array}{l}\text { Wie: kwetsbare - } \\
\text { groepen bur- } \\
\text { gers die te } \\
\text { maken krijgen } \\
\text { met decentrali- } \\
\text { saties } \\
\text { Basis: } \\
\text { verschillende } \\
\text { vormen van } \\
\text { expertise, } \\
\text { gedeelde erva- } \\
\text { ringen, waarden - } \\
\text { etc }\end{array}$ & $\begin{array}{l}\text { Informele auto- } \\
\text { risatie en ver- } \\
\text { antwoording via } \\
\text { uitwisseling van } \\
\text { ideeën in media, } \\
\text { starten } \\
\text { publieksacties } \\
\text { en bijeenkom- } \\
\text { sten met } \\
\text { gemeentebe- } \\
\text { stuur; } \\
\text { Toehorend } \\
\text { publiek wisse- } \\
\text { lend: grote } \\
\text { publiek; } \\
\text { gemeentebe- } \\
\text { stuur }\end{array}$ & . & $\begin{array}{l}\text { Expliciete claim } \\
\text { kwetsbare } \\
\text { groepen te ver- } \\
\text { tegenwoordigen } \\
\text { Afhankelijke } \\
\text { positie (uitnodi- } \\
\text { ging overheid, } \\
\text { gehoor bij } \\
\text { media etc.) } \\
\text { Gevaar van } \\
\text { inkapseling }\end{array}$ \\
\hline
\end{tabular}

\section{Conclusie}

In dit artikel hebben we een eerste verkenning gemaakt van hoe de stemmen van patiënten en cliënten via de weg van vertegenwoordiging kunnen doorklinken bij de drie decentralisaties in het sociale domein. Het begrip 'vertegenwoordigende claim' biedt daarbij de mogelijkheid om een diversiteit aan vertegenwoordigingskanalen te exploreren, ook buiten de bekende, formele kanalen als gemeenteraden om. Deze inventarisatie levert een gemixt beeld op van de democratische kwaliteit van de decentralisaties via de weg van vertegenwoordiging; de verschillende vertegenwoordigingskanalen leveren allemaal knelpunten op. Wel is duidelijk dat er een veelheid aan vertegenwoordigingsclaims te vinden is die op een variëteit aan vertegenwoordigingsaanspraken gebaseerd zijn (bijvoorbeeld ervaringen, professionele kennis, politiek mandaat et cetera). De vertegenwoordigingsrelatie in termen van autorisatie en verantwoording neemt ook verschillende vormen aan en is zowel formeel als informeel. Hoewel zelfbenoemde niet-gekozen vertegenwoordigers nog maar beperkt in actie lijken te komen en het nog niet duidelijk is in hoeverre zij ook op lokaal niveau een vuist kunnen gaan maken, laat de analyse wel zien dat met name zij de claim maken kwetsbare groepen te vertegenwoordigen die vanouds niet worden gehoord. Zij zouden dus een uitstekend kanaal kunnen bieden om de democratische kwaliteit van de decentralisaties te versterken. En zeker op het moment dat cliënten en patiënten na 1 januari 2015 direct te maken krijgen met de concrete gevolgen van de decentralisaties, kunnen zij die rol op zich nemen. Voordeel van deze niet-gekozen vertegenwoordigers vergeleken met gekozen vertegenwoordiging is dat zij expliciet de belangen van specifieke groepen kunnen vertegenwoordigen (bijvoorbeeld jeugd) op momenten dat dit nodig is. Bovendien moeten zij werk verrichten om hun claims expliciet te maken en anderen van de toegevoegde waarde en legitimiteit daarvan te overtuigen (Saward, 2009).

De gelaagde vertegenwoordigingsstructuur brengt de mogelijkheid van strijd met zich mee over wie de legitieme vertegenwoordiger is van welke groep. Verschil- 
lende actoren kunnen elkaars zeggenschap betwisten (Montanaro, 2012). Bovendien zijn de criteria waarop claims gebaseerd zijn, zoals deskundigheid en representativiteit, ambigu en onderwerp van discussie (zie ook Schrijvers \& Couperus, 2013). Het voordeel is wel dat in die strijd vertegenwoordigingsclaims geëxpliciteerd, geaccepteerd en daarmee gelegitimeerd moeten worden, wat de vertegenwoordigingsrelatie juist kan versterken. De gelaagde/meervoudige vertegenwoordigingsstructuur kan daarnaast ook positief worden beoordeeld, omdat op deze manier verschillende groepen burgers vertegenwoordigd worden. Juist in samenhang kunnen zij de democratische kwaliteit van vertegenwoordiging borgen. Hanna Pitkin verwoordde dat als volgt:

'Political representation is primarily a public institutionalized arrangement involving many people and groups, and operating in the complex ways of large scale social arrangements. What makes it representation is not any single action by any one participant but the overall structure and functioning of the system, the patterns emerging from the multiple activities of many people.' (Pitkin, 1967, 221-222)

Het belang van vertegenwoordiging voor een democratie en het constant verbeteren daarvan is reeds erkend (Urbinati, 2006). Door vanuit het brede perspectief van de vertegenwoordigende claim te kijken kan dit vertegenwoordigende systeem verder worden vormgegeven en een bijdrage leveren aan de 'continuing but not hopeless challenge' (Pitkin, 1967, 240) om op democratische wijze invulling te geven aan vertegenwoordiging.

Verder empirisch onderzoek is nodig om inzicht te krijgen in de bredere structuur van vertegenwoordiging en daarmee de interactie tussen verschillende vertegenwoordigingskanalen in de praktijk. Om een duidelijker uitspraak te doen over de democratische kwaliteit van de decentralisaties en de rol die vertegenwoordiging daarbij kan spelen, is het van belang om meer inzicht te krijgen in de verschillende vertegenwoordigingsclaims en hoe deze zich tot elkaar verhouden. Empirisch onderzoek naar vertegenwoordigende claims staat nog in de kinderschoenen (De Wilde, 2013). Onderzoek zou zich moeten richten op actoren die vertegenwoordigingsclaims maken en waar deze claims op gebaseerd zijn. Vervolgens is het van belang inzicht te krijgen in de formele en informele autorisatie en verantwoordingsstructuren die achter deze claims liggen. Ook zou onderzocht moeten worden welke claims worden geaccepteerd door besluitvormers en vertegenwoordigden en waar dat oordeel op gebaseerd is. Tot slot is inzicht nodig in de impact van de claims op besluitvorming. Dit alles biedt de noodzakelijke empirische ondergrond voor wat op het eerste oog een verbeterde invulling op de representatieve democratie kan zijn.

\section{Noten}

1 Andere koepelorganisaties van patiënten zijn iets terughoudender in hun claim, maar ook voor hen geldt dat ze claimen een bredere groep dan alleen de leden van de aange- 
sloten organisaties. Regionale zorgbelangorganisaties claimen bijvoorbeeld de belangen te behartigen van alle zorgvragers in de regio (www.zorgbelang-nederland.nl), en Ieder(in), de koepelorganisatie van mensen met een lichamelijke handicap, verstandelijke beperking of chronisch ziekte, claimt al deze mensen te vertegenwoordigen (www. iederin.nl).

2 De NPCF kan bij uitstek worden gezien als een professionele patiëntenorganisatie, waar professionele medewerkers werken en geen ervaringsdeskundige vrijwilligers werken. Directeur Wilna Wind heeft bijvoorbeeld een achtergrond in de vakbeweging, voorzitter Gerda Verbeet is oud-Kamerlid en oud-Tweede Kamervoorzitter. In veel aandoeningspecifieke patiëntenorganisaties zijn vaak wel patiënten met ervaringskennis actief, al dan niet in samenwerking met professionele medewerkers.

3 De oprichters van de petitie wisten uiteindelijk 96.209 handtekeningen te verzamelen. Zie voor meer informatie www.petitiejeugdggz.nl/en voor een overzicht van krantenartikelen over dit thema www.petitiejeugdggz.nl/media/.

\section{Literatuur}

Berg, J. van den (2013). De spagaat van de gedecentraliseerde eenheidsstaat. Beleid \& Maatschappij, 40 (2): 205-220.

Blauw, W. (2010). Kansen voor Utrechtse kerken binnen de WMO. Tijdschrift voor Religie, Recht en Beleid, 1 (2): 63-75.

Boer, N. de, \& Lans, J. van der (2011). Burgerkracht: de toekomst van sociaal werk in Nederland. Den Haag: Raad voor Maatschappelijke Ontwikkeling.

Boogers, M.J.G.J.A., Schaap, L., Collignon, E.D., \& Karsten, N. (2009). Decentralisatie als opgave. Bestuurswetenschappen, 63 (1): 29-49.

Boogers, M. (2014). Decentralisaties in het sociale domein: meer politiek en minder democratie? Beleid \& Maatschappij, 41: 146-150.

Boonen, L.H.H.M (2009). Consumer Channeling in Health Care: (im)possible? Rotterdam: Erasmus Universiteit Rotterdam.

Bovenkamp, H. van de (2010). The Limits of Patient Power (diss. Erasmus Universiteit Rotterdam).

Bovenkamp, H. van de, Trappenburg M., \& Grit, K. (2010). Patient participation in collective healthcare decision making: the Dutch model. Health Expectations, 13: 73-85.

Bovenkamp, H. van de, Vollaard, H., Grit, K., \& Trappenburg M.J. (2013). Voice and choice by delegation. Journal of Health Politics, Policy and Law, 38 (1): 57-87.

Bovens, M., \& Wille, A. (2011). Diplomademocratie: over de spanning tussen meritocratie en democratie. Amsterdam: Uitgeverij Bert Bakker.

Cromwijk, R., Lucassen, A., Winsemius, A., Alblas, M., \& Sok, K. (2010). Wmo-raden in beeld: over de invloed van Wmo-raden. Utrecht: Movisie.

Denters, B. (2012). A dirty job that needs to be done! De rol van het raadslid in de ogen van Nederlandse burgers. Bestuurswetenschappen, 3: 14-34.

Dowding, K., \& John, P. (2009). The value of choice in public policy. Public Administration, 87 (2): 219-233.

Gaag, R. van der, Glisen, R., \& Mak, J. (2013). Participatie in zicht: gemeenten, jeugdigen, ouders en jeugdzorgcliënten in de transitie jeugdzorg. Utrecht: Verwey-Jonker Instituut.

Graaf, L. de, Schaap, L., Boogers, M., \& Mulder, L. (2009). Lokale referenda in Nederland sinds 1990. Openbaar Bestuur, 19 (8): 23-31.

Held, D. (2006). Models of Democracy. Cambridge: Polity Press. 
Hibbing, J.R., \& Theiss-Morse, E. (2002). Stealth democracy: Americans' beliefs about how government should work. Cambridge/New York: Cambridge University Press.

Hoogerwerf, R., Nievers, E., \& Scholten, C. (2004). De invloed van cliëntenraden. Het verzwaard adviesrecht in de dagelijkse praktijk van cliëntenraadsperspectief. Leiden: Research voor Beleid.

Kaap, H. van der (2006). Politieke representatie en lokale democratie (diss. Universiteit Twente).

Klaveren, S.M. van, \& Poortvliet, E.P. (2011). WMO raden aan het werk: onderzoek naar de effectiviteit en representativiteit van WMO-raden. Zoetermeer: Research voor Beleid.

Klerk, M. de, Gilsing, R., \& Timmermans, J. (red.) (2010). Op weg met de Wmo. Den Haag: Sociaal en Cultureel Planbureau.

KNMG (2013). Visie Versterking Medische Zorg aan jeugdigen.

KNMG (2014a). Reactie KNMG Jeugdwet. Brief aan de Eerste Kamer (20 januari).

KNMG (2014b). Reactie KNMG op nadere Memorie van Antwoord inzake Jeugdwet (4 februari).

Koster, Y. de (2014). Minder kiezers dan ooit. Binnenlands Bestuur. www. binnenlandsbestuur.nl/bestuur-en-organisatie/nieuws/minder-kiezers-dan-ooit. 9232503.lynkx, geraadpleegd op 20 maart 2014

Kraan, W.G.M. van der, \& Meurs, P. (2008). Effectieve medezeggenschap. Een verkennend onderzoek naar effectieve vormgeving van medezeggenschap van cliënten in algemene ziekenhuizen. Rotterdam: iBMG.

Leyenaar, M. (2009). Burger aan zet. Vormen van burgerparticipatie: inventarisatie en evaluatie. Den Haag: Ministerie van Binnenlandse Zaken en Koninkrijksrelaties.

Loots, J., \& Peeters, P.H. (2013). De gemeenteraad heeft geen toekomst. Eindhoven: Pepijn.

Lub, V., Sprinhuizen, A., \& Cromwijk, R. (2010). Wmo Trendrapport 2010: het spel op het maatschappelijk middenveld. Utrecht: Movisie.

Manin, B. (1997). The principles of representative government. Cambridge: Cambridge University Press.

Manin, B., Przeworski, A., \& Stokes, S.C. (1999). Introduction. In: A. Przeworski, S.C. Stokes \& B. Manin (Eds.), Democracy, accountability and representation. Cambridge: Cambridge University Press, 1-26.

Mansbridge, J. (2003). Rethinking representation. American Political Science Review, 97 (4): 515-528.

Mansbridge, J. (2011). Clarifying the concept of representation. American Political Science Review, 105 (3): 621-630.

Mayer, I., Edelenbos, J., \& Monnikhof, R. (2002). Stormram of stut? Democratische dilemma's van interactieve beleidsontwikkeling. In: J. van Holsteyn \& C. Mudde (red), Democratie in verval? Amsterdam: Boom.

Michels, A. (2011). De democratische waarde van burgerparticipatie: interactief bestuur en deliberatieve fora. Bestuurskunde, 2: 75-84.

Ministerie van Volksgezondheid, Welzijn en Sport (2013). Concept Memorie van Toelichting Wet maatschappelijke ondersteuning 2015 (16 augustus).

Montanaro, L. (2012). The Democratic Legitimacy of Self-Appointed Representatives. The Journal of Politics, 74 (4): 1094-1107.

Morone, J.A., \& Jacobs, L.R. (2005). Introduction: Health and Wealth in the Good Society. In: J.A. Morone \& L.R. Jacobs (Eds.), Healthy, Wealthy, and Fair: Health Care and the Good Society. New York: Oxford University Press, 2-18.

Munster, R. van, Sok, K., Verschelling, M., \& Lucassen, A. (2012). Cliëntenparticipatie in de voorbereiding van de AWBZ-transitie. Utrecht: Movisie. 
NHG/LHV (2013). Inbreng LHV en NHG voor verslag Jeugdwet (Kamerstuknummer 33684). Brief aan de Tweede Kamer (10 september).

Noordegraaf, H. (2012). Kerk en Wmo: de eerste vijf jaren (2007-2011). Een onderzoek naar (kritische) participatie van kerken in de Wmo. Groningen: Stichting Rotterdam.

Oenen, G. van (2011). Nu even niet! Over de interpassieve samenleving. Amsterdam: Van Gennep.

Oers, J.A.M. van (2002). Gezondheid op koers? Volksgezondheid Toekomst Verkenning.

Oudenampsen, D., \& Nederland, T. (2013). De rol van burgers in de transitie van AWBZ naar Wmo. Utrecht: Verwey-Jonker Instituut.

Penning, L. (2009). Invloed van Wmo-raden: machtsfactor of excuusorgaan? Utrecht: Movisie. Pitkin, H.F. (1967). The concept of representation. Berkeley: University of California.

Pitkin, H.F. (2004). Representation and democracy: uneasy alliance. Scandinavian Political Studies, 27 (3): 335-342.

Plotke, D. (1997). Representation is democracy. Constellations, 4 (1): 19-34.

Protestantse Kerk Nederland (z.j.). Kerken en Wmo. www.pkn.nl/actueel/Nieuws/ nieuwsoverzicht/Paginas/Kerken-en-Wmo.aspx, geraadpleegd op 22 mei 2014.

Raad voor het openbaar bestuur (2013). Reactie op Decentralisatiebrief dhr. Plasterk (23 april).

Regeerakkoord VVD-PvdA (2012). Bruggen slaan.

Rekenkamercommissies B4-gemeenten (2013). Klaar voor de start? Onderzoek naar de kaderstellende en controlerende rol van gemeenteraden rond de transitie jeugdzorg in B4gemeenten.

Rooms-Katholieke Kerk (2007). Diaconie en Wmo. www.rkdiaconie.nl/uploadedDocs/ WMOkaternRKkerk.pdf, geraadpleegd op 22 mei 2014.

Rouvoet, A. (2014). Brief hervorming langdurige zorg aan de vaste commissie voor VWS. Zeist.

Savornin Lohman, J. de, Rijkschroeff, R., Oudenampsen, D., Gelder, K. van, \& Overbeek, R. van (2000). Evaluatie Wet medezeggenschap cliënten zorgsector. Achtergrondstudies per sector. Utrecht: Verwey Jonker Instituut.

Saward, M. (2006). Democracy and citizenship: expanding domains. In: J.S. Dryzek, B. Honig \& A. Phillips (Eds.), The Oxford Handbook of Political Theory. Oxford: Oxford University Press, 400-421.

Saward, M. (2009). Authorization and authenticity: representation and the unelected. The Journal of Political Philosophy, 17 (1): 1-22.

Saward, M. (2010). The Representative Claim. Oxford: Oxford University Press.

Schillemans, T., Bovenkamp, H. van de, \& Trappenburg M. (te verschijnen). From 'Major Decisions' to 'Everyday Quality'. Direct Accountability to Clients.

Schrijvers, E., \& Couperus, S. (2013). Voorbij verkiezing en parlement. Alternatieve representatie in Nederland na 1870. In: R. Aerts \& P. de Goede (red.), Omstreden democratie: over de problemen van een succesverhaal. Amsterdam: Boom.

SGBO (2006). Gemeenteraadsverkiezingen in zicht, 1982-2006: trends in opkomst, interesse en vertrouwen. Den Haag: SGBO.

Skocpol, T. (2003). Diminished democracy: from membership to management in American civic life. Norman: University of Oklahoma Press.

Strolovitch, D.Z. (2006). Do interest groups represent the disadvantaged? Advocacy at the intersections of race, class and gender. The Journal of Politics, 68: 894-910.

Trappenburg, M. (2008). Genoeg is genoeg. Amsterdam: Amsterdam University Press.

Tweede Kamer (2009/10). Brief staatssecretaris aan de Tweede Kamer (18 september), 29538/31795, nr. 107, 12.

Tweede Kamer (2013/14). Motie Bergkamp, 33841, nr. 161. 
Urbinati, N. (2006). Representative democracy: principles and genealogy. Chicago/Londen: The University of Chicago Press.

Urbinati, N., \& Warren, M.E. (2008). The concept of representation in contemporary democratic theory. Annual Review of Political Science, 11: 387-412.

Veldheer, V., Jonker, J.J., Noije, L. van, \& Vrooman, C. (2012). Een beroep op de burger: minder verzorgingsstaat, meer eigen verantwoordelijkheid? Sociaal en cultureel rapport 2012. Den Haag: Sociaal en Cultureel Planbureau.

Verba, S., \& Nie, N. (1972). Participation in America: political democracy and social equality. New York: Harper \& Row Publishers.

Volkskrant, de (2013, 4 juli). Ze hebben geen idee wat er op ze af komt.

Vonk, F., Kromhout, M., Feijten, P., \& Marangos, A.M. (2013). Gemeentelijk Wmo-beleid 2010 (tweede Wmo-evaluatie: deelrapport gemeentelijk beleid). Den Haag: Sociaal en Cultureel Planbureau.

Wilde, P. de (2013). Representative claims analysis: theory meets method. Journal of European Public Policy, 20 (2): 278-294.

Wind, W. (2013). Decentralisatie versplintert de langdurige zorg. Skipr, 29 augustus.

\section{Websites}

www.tns-nipo.com/nieuws/nieuwsberichten/gemeenteraadsverkiezingen-gaan-eindelijkecht-loka/, Gemeenteraadsverkiezingen gaan eindelijk écht lokaal, geraadpleegd op 21 februari 2014.

www.ipsos-nederland.nl/content.asp?targetid=1270, GR2014: Wat vonden kiezers belangrijk?, geraadpleegd op 1 april 2014.

www.npcf.nl/index.php?option=com_content\&view=category\&layout=blog\&id=5\&

Itemid=14, geraadpleegd op 5 mei 2014.

www.petitiejeugdggz.nl/media/, geraadpleegd op 5 mei 2014. 